\title{
Transsphinctericanorectal reconstruction of ambiguous genitalia: an innovative approach to neovaginoplasty, pioneer in Brazil
}

\author{
Intersexuality Unit of the Children's Hospital Darcy Vargas \\ of São Paulo - SP, Brazil
}

\begin{abstract}
The authors, based upon previous experience in the treatment of ten children with cloacal abnormalities, among which two with female pseudohermaphroditism with cloaca, hereby present a pioneer experience in Brazil, with the "posterior sagittal transsphinctericanorectalurethrovaginoplasty" a surgical approach to neovaginoplasty described by "Cripps/Peña", which was utilized for the reconstruction of the genitalia of three intersexuated adolescents with protective colostomy, who presented an urogenital sinus, high vaginal implantation and a normal rectum. One patient was an adrenal female pseudohermaphrodite and two were male pseudohermaphrodites. The authors present a brief report on the three cases, describe the surgical procedure, relate on the anatomy of the urogenital sinus and discuss surgical indications, diagnosis and results, comparing them to the reviewed international literature.
\end{abstract}

UNITERMS: Ambiguous genitalia. Pseudohermaphroditism. Posterior sagittal transsphinctericanorectal approach. Intersexuality. Vaginoplasty.

\section{INTRODUCTION}

M anagement of the ambiguous genitalia (AG), of the female gender with urogenital sinus (UGS), high vaginal agenesis and normal rectum, has been a major challenge to the pediatric surgeon, for whom the main objective is to propitiate a normal sexual function to bearers of this type of genitalia, including a possibility of procreation, as well as really upon the objectives of management regarding control of defecation and urination,

\section{Address for correspondence:}

Albany Braz

Rua Cubatẫo, 1.209 - Vila Mariana

São Paulo / SP - Brasil - CEP 04013-044 and also of the anatomical and esthetical aspects, which are very important.

At the Children's Hospital "Darcy Vargas" (CHDV), we had the opportunity to acquire and collect in these last seventeen years $(2-6,22,23)$ some experience with the diagnosis and clinical-surgical management of $\mathbf{A G}$, especially with those cases requiring reconstruction of the external genitalia, thus complementing the experience with the correction of anorectal abnormalities and with that of our ten cases of cloacal abnormalities (CA) (2) which were submitted to a "posterior sagittal anorectalurethrovaginoplasty" (7,13,14,16,18) (PSARUVP). It further induced us to apply this procedure with modifications (Cripps/ Peña's tecnique) (21) to intersexuated patients, to correct the UGS with high vaginal implantation (agenesis) and normal rectum.

In the current paper we shall present our experience with the surgical approach posterior sagittal transsphinctericanorectalurethrovaginoplasty (PSTSARUVP) for 
Table 1

Origins and ages of patients; dates of surgeries and evolution

\begin{tabular}{|c|c|c|c|c|}
\hline \multicolumn{5}{|c|}{$\begin{array}{l}\text { INTERSEXUALITY UNIT - CHILDREN'S HOSPITAL “DARCY VARGAS" } \\
\text { TRANSSPHINCTERICANORECTALURETHROVAGINOPLASTY }\end{array}$} \\
\hline CASE & ORIGIN & AGE AT SURG. & $\begin{array}{l}\text { DATE } \\
\text { PSTSARUVP }\end{array}$ & EVOLUTION \\
\hline 1 & $\begin{array}{l}\text { SANTANA VARGEM } \\
\text { (MINAS GERAIS) }\end{array}$ & $\begin{array}{l}13 \text { YEARS } \\
09 \text { MONTHS }\end{array}$ & $\begin{array}{l}\text { 2/2/93 } \\
\text { STOOLURINE }\end{array}$ & CONTINENT \\
\hline 2 & $\begin{array}{l}\text { NOVA REDENÇÃO } \\
\text { (BAHIA) }\end{array}$ & $\begin{array}{l}13 \text { YEARS } \\
06 \text { MONTHS }\end{array}$ & $\begin{array}{l}\text { 4/27/93 } \\
\text { STOOL/URINE }\end{array}$ & CONTINENT \\
\hline 3 & $\begin{array}{l}\text { PARAGUASSU PAUL. } \\
\text { (SÅO PAULO) }\end{array}$ & $\begin{array}{l}15 \text { YEARS } \\
10 \text { MONTHS }\end{array}$ & $\begin{array}{l}\text { 7/8/93 } \\
\text { STOOLURINE }\end{array}$ & CONTINENT \\
\hline
\end{tabular}

neovaginoplasty (NVP) described by "Cripps/Peña” (21), where the cases and procedures shall also be discussed comparing and relating them to the worldwide incidence.

\section{MATERIALS AND METHODS}

From 1978 to 1995 , at the CHDV, 235 patients with abnormalities of the external genitalia were admitted and $163(69.5 \%)$ underwent some type of surgery, of these in three cases (1.8\%) the reconstruction of UGS with high vaginal agenesia and normal rectum was undertaken by PSTSARUVP with protective colostomy.
Two patients came from other States of the country $(66.6 \%)$ and one came from a city in the interior of the São Paulo State $(33,3 \%)$, Table 1.

At the time of surgery the ages of the three patients weres respectively, of 13 years and 9 months, 13 years and 6 months, 15 years and 10 months, with a median of 14 years and 4 months, Table 1 .

Regarding race, one was negro and two were white, Table 2.

As for diagnosis, we had one patient with female pseudohermaphroditism (FPH), bearer of adrenal congenital hyperplasia (ACH) and "sodic diabetes" (salt loosing) resulting from defect of the enzime 21 hydroxylases.

Other two with male pseudohermaphroditism (MPH) incomplete syndrome type I, that is, one was familial MPH

Table 2

Identification and diagnosis of the patients

INTERSEXUALITY UNIT - CHILDREN'S HOSPITAL "DARCY VARGAS" TRANSSPHINCTERICANORECTALURETHROVAGINOPLASTY

\begin{tabular}{lllllll} 
CASE & REGISTER & PATIENT & RACE & DIAGNOSIS & BIRTH DATE & 1st CONS \\
\hline 1 & 070468 & TAR & B. & FPH $($ ACH $)$ & $05 / 03 / 79$ & $03 / 16 / 81$ \\
2 & 106260 & NSST & W. & MPH (TFS) & $10 / 06 / 79$ & $07 / 04 / 83$ \\
3 & 144558 & FAF & W. & MPH (TRS) & $09 / 17 / 77$ & $05 / 15 / 87$ \\
\hline
\end{tabular}




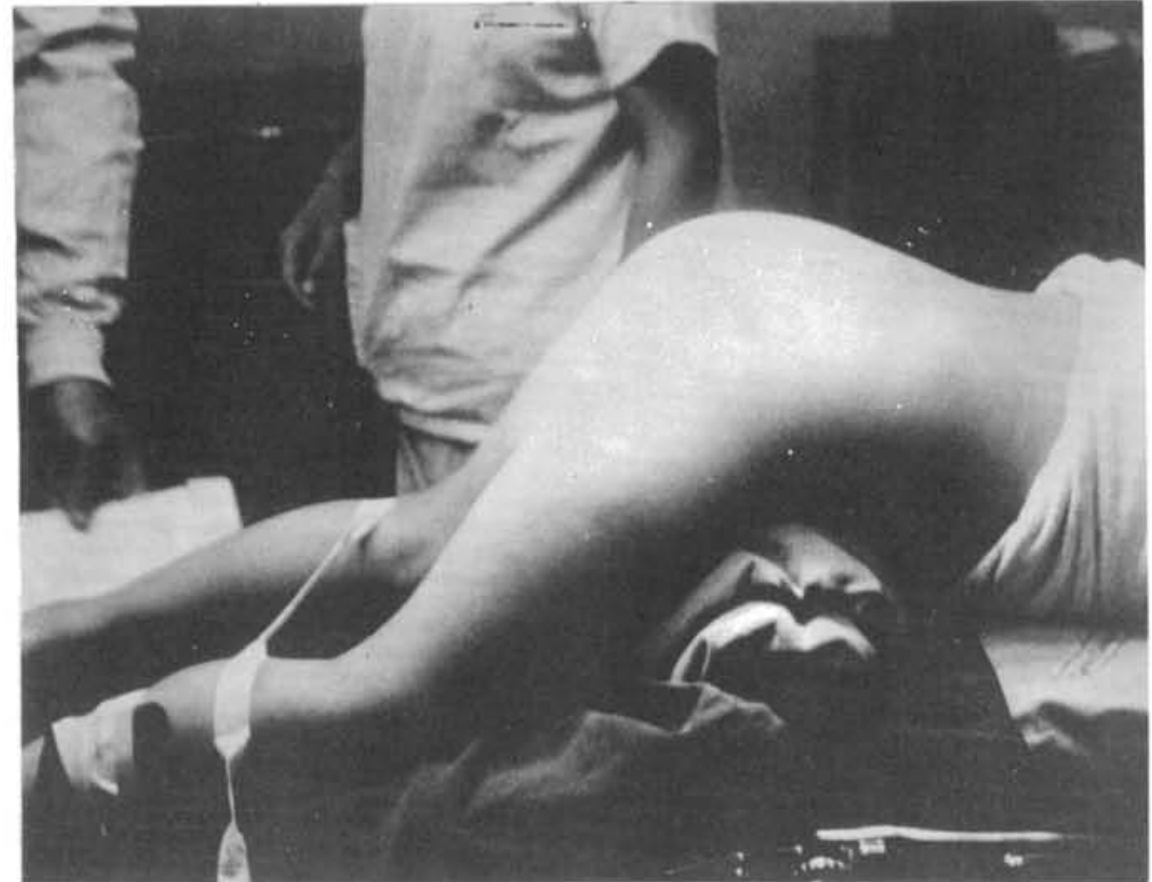

Figure 1 - Prone genupeitoral position, "open knife" feature adequate for the performance of PSTSARUVP.

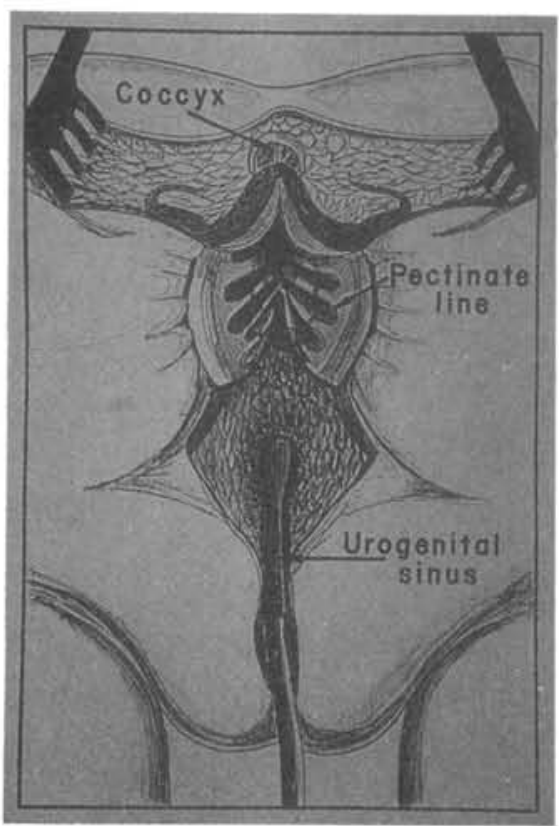

Figure 2 - Posterior sagittal sacroperineal incision with separation of the anus and of the anterior and posterior walls of the rectum which acquire a bivalvular feature (transsphinctericanorectal incision), which permit viewing of the pectineal line and of the urogenital sinus.

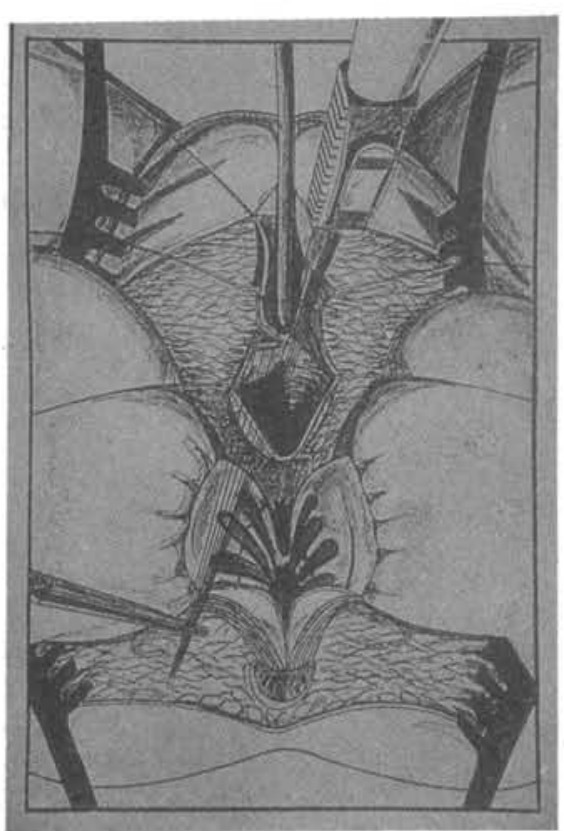

Figure 3 - Sagittal incision of the urogenital sinus posterior wall and of the vaginal opening near the junction with the urethra. derived from a peripheral deficiency of androgenic receptors, also called "testicular feminilization syndrome" (TFS) and the other was a MPH with a "testicular regression syndrome" (TRS) Table 2.

The neovaginoplasties were undertaken by one of us (A.B.) after assessment of hormone levels, determination of the karyotype, Xray tests (urogenitalgraphy or urinary urethrocystovaginography) and endoscopic ones (urethrocystovaginoscopy); performance of a sigmoidostomy; vesical catheterism with a "Foley" probe through the UGS; rectal irrigation with a solution of "Iodinepovidone" and a profilactic therapy with antibiotics during the pre and postoperatory stages, (Amikacin and Metronidazole) were also undertaken.

\section{DESCRIPTION OF THE PROCEDURE}

\section{"Posterior sagittal transsphincte- ricanorectalurethrovaginoplasty"}

The patient is set in knee-chest (genupectoral) prone position "open jack knife" feature (Figure 1).

Surgery begins with a longitudinal posterior sagittal incision of the skin (at the intergluteal midline), starting from the sacrococcygeal region passing through the anus extending until the meatus of the urogenital sinus.

The incision is sagittally deepened "always using the electrocautery and keeping to the middle line, so as to avoid nerve injuries and also to divide into symmetric halves", the anus elevator muscle, "muscle complex" and jointly with the external anal 


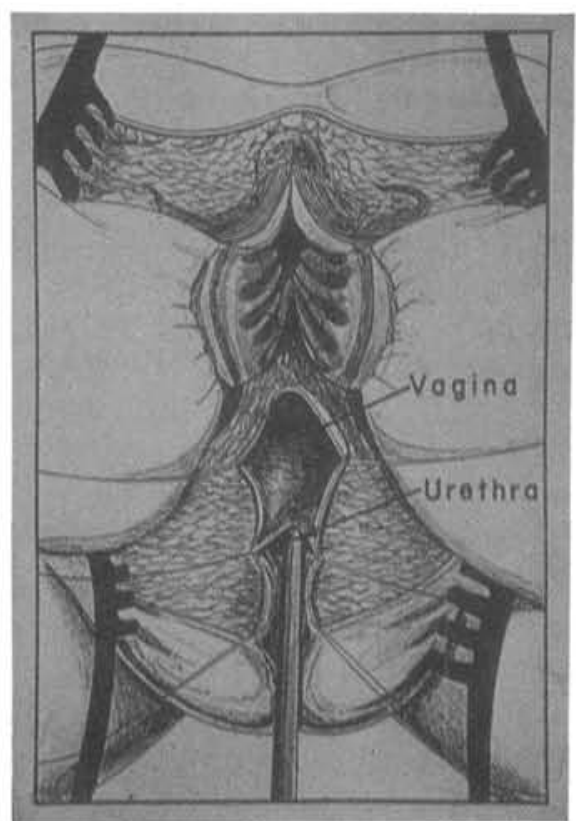

Figure 4 - Maneuvres with multiple sutures on the borders of the vagina (sutures 6-0), while separating it from the urethra with the electrocautery.

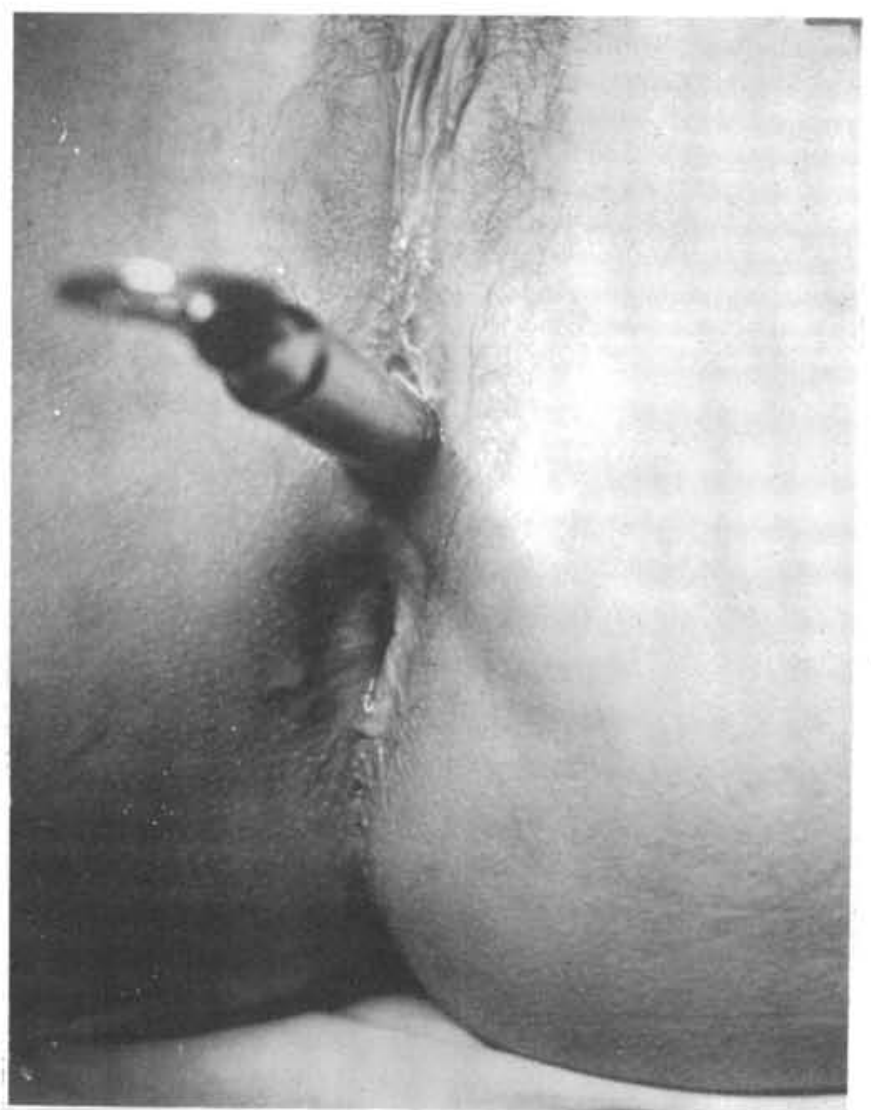

Figure 5 - Final aspect of reconstructions of the urethra, vagina, anus, rectum and perineum by means of PSTSARUVP with a vulvar introitus corresponding to the width of a N.20 Hegar bougie.

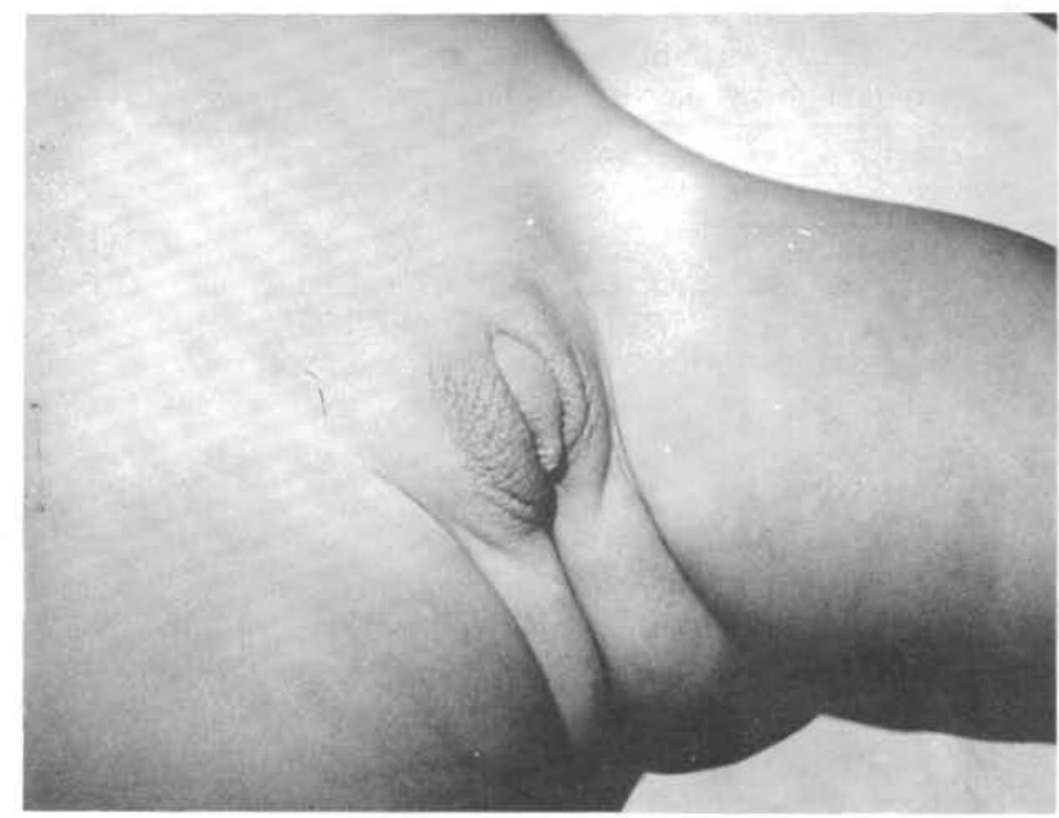

Figure 6 - Patient (case 1) with ambiguous genitalia at the time of the first consultation, note clitoromegaly and rugated labioscrotal folds.

sphincter, the posterior and anterior walls of the rectum. By this procedure the rectum walls gain a bivalvular feature and through them we perform all surgical dissections (Figure 2).

The incision will extend and penetrate deeper until it reaches the urogenital sinus, which is exposed, and opened sagittally on its posterior wall, thence the vagina and urethra can be visualized and identified (Figure 3).

For a better visualization, identification and dissection of all these structures we utilize the "Weitlander" separator and the electromiostimulator, further, in order to avoid injuries and enhance dissection of the vagina, "60 " sutures are applied to its borders, while it is being separated from the urethra with the electrocautery (Figure 4). The vagina is dissected from the urethra, with the electrocautery, until its full separation from the bladder, near to the peritoneal reflection.

The lateral fixation strands of the vagina are parted and after full liberation, mobilization and elongation of the vagina one proceeds to the reconstruction of the neourethra (urethrorhaphy, including the sphincter muscles) by two planes of sutures, interrupted over the "Foley" probe, with retarded absorption sutures " $5-0$ ".

Afterwards we undertake the suture from the vaginal ostium to the perineum, quite close to the urethral neomeatus.

Reconstruction of the perineal body and of all muscles (anus elevator muscles and those of the "muscle complex") is performed, aided by electromiostimulation 
Table 3

Surgeries undertaken on patient, case $n .1$

SURGERIES ON CASE N. 1 (T.A.R.)
$(10 / 4 / 82)$

$(1 / 21 / 93)$

$(2 / 2 / 93)$

$(7 / 25 / 93)$
Table 4

Surgeries undertaken on patient, case n.2

SURGERIES ON CASE N. 2 (N.S.S.T.)

\begin{tabular}{lll}
1 & CLITOROPLASTY & $(1 / 16 / 84)$ \\
2 & GONADECTOMY (TESTICLE) & $(4 / 15 / 86)$ \\
3 & SIGMOIDOSTOMY & $(2 / 9 / 93)$ \\
4 & NEOVAGINOPLASTY (PSTSARUVP) & $(4 / 27 / 93)$ \\
5 & CLOSURE OF THE COLOSTOMY & $(6 / 1 / 93)$ \\
\hline
\end{tabular}

Surgical interventions for the correction of the external genitalia are reported on Table 3 .

At 15 years of age she is continent for stool and urine, continues receiving $9 \mathrm{a}$-fluorhydrocortisone and prednisone; she has regular menses, normal breasts and pubo-genital hair growth (Figure 7). Is using a vaginal inflatable stent.

\section{Case 2}

N.S.S.T., when she was 3 years and nine month old was admitted at the $\mathbf{C H D V}$ with $\mathbf{A G}$ and was assigned to

\section{CASE REPORTS}

\section{Case 1}

T.A.R., was admitted at CHDV with AG (Figure 6) when one year and ten months old, and was assigned to the male gender (D.A.R.), having been submitted to diagnostic investigation, and was proven to be FPH with ACH, Table 2.

At clinical examination exhibited clitoromegaly, urethral meatus at the penile shaft, labioscrotal fusion, rugated labioscrotal folds of increased volume, deprived of pubogenital hair growth; inguino-scrotal gonads were not palpable, but at rectal examination the womb was palpable.

Laboratory assessments showed presence of Baar corpuscles, karyotype $46 \mathrm{XX}$, high plasma level of the 17ahydroxyprogesterone (over $5 \mathrm{ug} / \mathrm{ml}$ ), the bone maturation corresponded to 28 months and urogenital X-ray and urethrovaginoscopy disclosed presence of UGS and womb.

She was reassigned to the female gender.

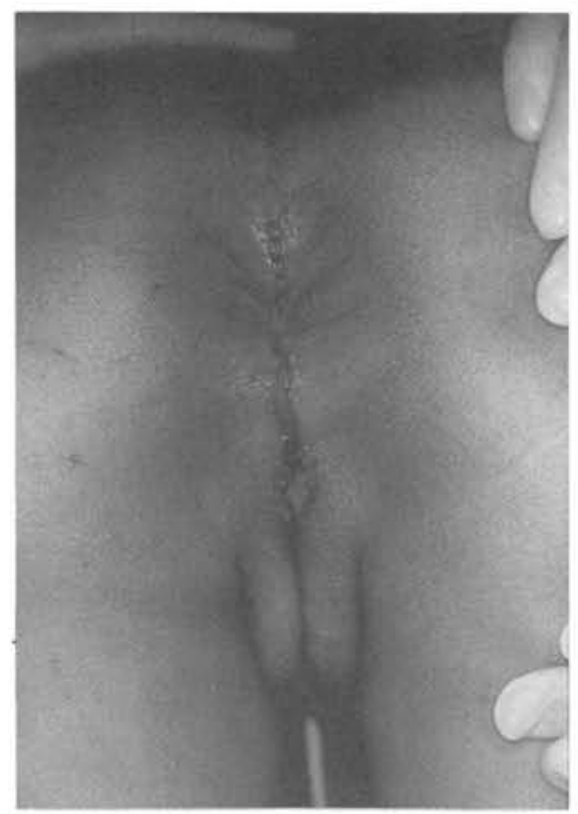

Figure 7 - Final aspect of patient genitalia (case 1) at immediate postoperatory by PSTSARUVP, observe the urethral probe, the vulvar introitus and the anus with their sutures. 


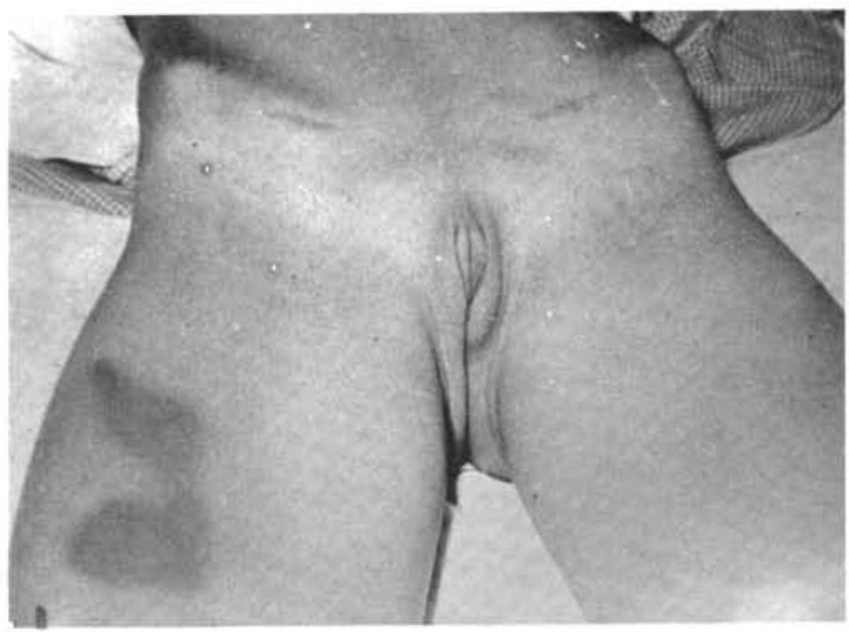

Figure 8 - Patient (case 2) with ambiguous genitalia post bilateral gonadectomy and clitoroglanuloplasty.

the female gender, having been submitted to diagnostic investigation, and proven to be MPH (STF), Table 2.

At clinical examination, presented clitoromegaly, urethral meatus at the penile shaft, labioscrotal fusion; normal labia majora with no folds, no pubogenital hair growth; inguinal gonads were palpable, but at rectal examination no womb was palpable (Figure 8).

At laboratory assessments, Baar corpuscles were absent, karyotype was $46 \mathrm{XY}$, and plasma levels of $17 \mathrm{a}-$ hydroxyprogesterone were normal, bone maturation was proportional to the chronological age and urinary urethrocystography and urethrovaginoscopy confirmed the presence of UGS, without womb.

The undertaken surgeries are reported on Table 4.

At 15 years of age is continent for stool and urine, still receiving estrogen therapy "Premarin" has no menses but has normal breasts and hair growth (Figures 5 and 9). Is using a vaginal inflatable stent.

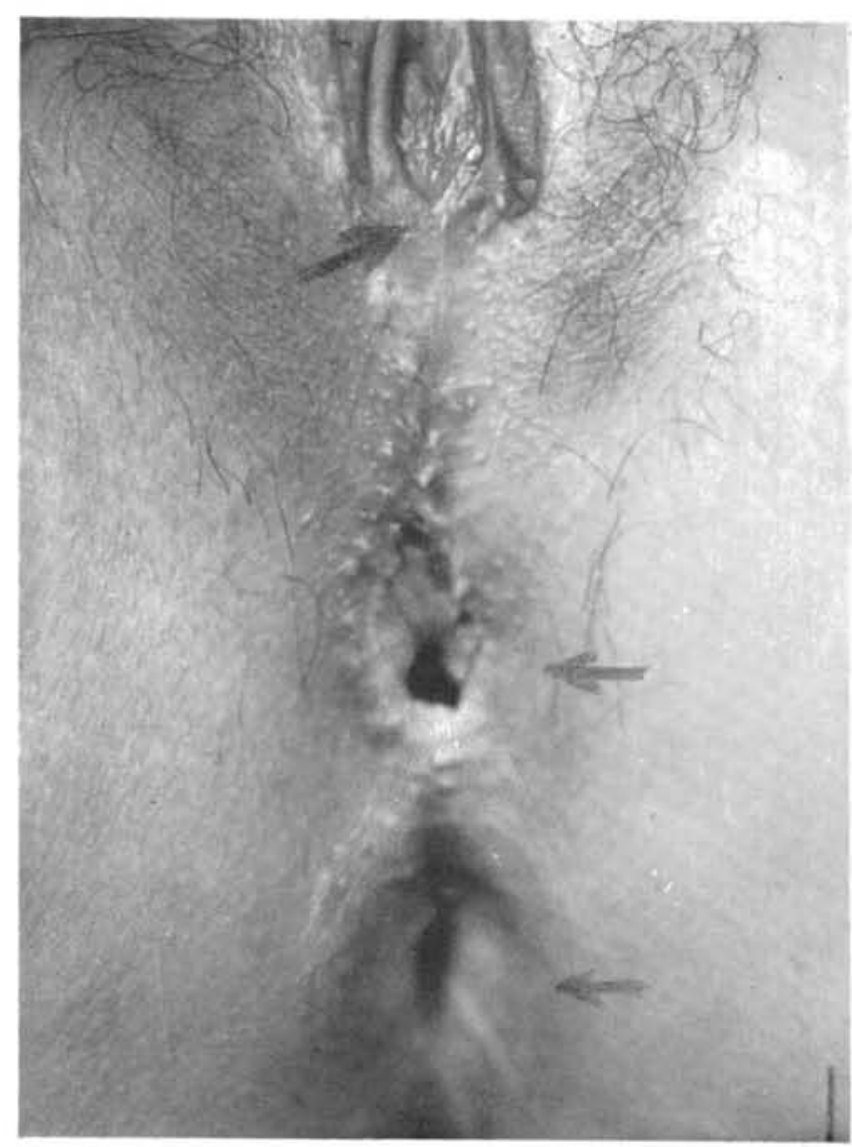

Figure 9 - Final aspect of the patient genitalia (case 2) after reconstruction by the PSTSARUVP approach, notice the urethra, vagina and anus in their typical positions (arrows).

\section{Case 3}

F.A.F., at 9 years and 8 months of age was admitted at the CHDV with a diagnosis of vaginal agenesia, and have been submitted to diagnostic investigation, ascertaining that she was MPH (TRS), Table 2.

$\begin{array}{lll}1 & \text { LAPAROTOMY (GONADAL AGENESIS) } & (1 / 4 / 88) \\ 2 & \text { SIGMOIDOSTOMY } & (6 / 29 / 93) \\ 3 & \text { NEOVAGINOPLASTY (PSTSARUVP) } & (7 / 8 / 93) \\ 4 & \text { NEOVAGINOSIGMOIDPLASTY (PSTSARUVSP) } & (11 / 16 / 93) \\ 5 & \text { CLOSURE OF THE COLOSTOMY } & (2 / 17 / 94)\end{array}$


At clinical examination presented normal clitoris, "hypospadic" urethral meatus, a scar at the labioscrotal fusion, rugated labia majora, no pubogenital hair growth, groin gonads were not palpable, nor, at rectal examination was the womb.

Laboratory assessments, showed absence of Baar corpuscles, karyotype 46XY, plasma levels of 17a-hydroxyprogesterone were normal, bone maturation was proportional to the chronological age and urinary urethrocystography and urethrovaginoscopy confirmed that she was a MPH (TRS), Table 2.

The undertaken surgeries are reported on Table 5.

At 18 years of age she is receiving estrogen therapy, "Premarin", and she has normal breasts, and pubogenital hair growth, (Figure 10), however has no menses. She is urine and stool continent. Due to a retraction of the vagina, she has undergone another surgery and a neovagina has been constructed with a loop of the sigmoid, Table 5.

\section{RESULTS}

In our casuistry, one patient (33\%) was reassigned to the female gender (Case 1) (Figures 6 and 7).

Clitoris of patients (cases 1 and 2) submitted to clitoroplasty have retained their full sensitivity.

Secondary sexual characteristics are well developed in all patients, as a result of the estrogen therapy in the case of two patients with MPH (cases 2 and 3 ). In case N. 1 with $\mathbf{A C H}$, administration of prednisone and $9 \alpha$ fluorhydrocortisone is still continued.

With respect to menstruation only case 1 (FPH) had regular menses $(33 \%)$, while the other two have uterine agenesis.

All patients have urinary and fecal continence.

Regarding to the enlargement of the vagina, in all of the cases the opening permits the passage of a N. 20

Hegar's bougie, (Figure 5), but at night these patients are using a vaginal inflatable stent to avoid "for lack of usage" stenosis or retraction of the introitus.

Finally, the esthetic features of the genitalia are extraordinary (Figures 7 and 9), but up to now, no patient has undertaken sexual intercourse (Figures 5, 7,9 and 10) and there is no record of death, nor interruption of the follow-up.

On Table 6, is recorded the statistical summary of results.

\section{DISCUSSION}

The urogenital sinus associated to a normal rectum is usually seen in patients with $\mathbf{A G}$, and is more frequent in cases of FPH with or without $\mathbf{A C H}$ and in a shorter degree in MPH or other forms of intersexuality, such as in mixed gonadal dysgenesia or even in true hermaphroditism.

There is a large spectrum in the constitution of the urogenital sinus, ranging from a vagina communicating with the urethra close to the perineum, whose treatment is much simpler $(7,13,14,16,18,21)$, to those in higher 
Table 6

Statistical summary of the evolution and results

INTERSEXUALITY UNIT - CHILDREN'S HOSPITAL "DARCY VARGAS"

TRANSSPHINCTERICANORECTALURETHROVAGINOPLASTY

CASUISTRY (3 PATIENTS)
N. OF CASES SURGERIES - EVOLUTION AND RESULTS

SEXUAL REASSIGNMENT

MENSES

URETHROVAGINAL FISTULA

RETRACTION OF THE VAGINA

CLITOROPLASTY

FECAL CONTINENCE

URINARY CONTINENCE

NEOVAGINOPLASTY (PSTSARUVP)

NEOVAGINOSIGMOIDPLASTY(PSTSARUVSP)

\section{PERCENTAGE}

$33.3 \%$

$33.3 \%$

$33.3 \%$

$33.3 \%$

$66.6 \%$

$100.0 \%$

$100.0 \%$

$100.0 \%$

$33.3 \%$ positions and nearer to the vesicular cervix, where they require more careful dissection and more difficult approaches to neovaginoplasty $(19,21)$.

For the repair of such virilized external genitalia of the female gender with UGS and normal rectum, a reductive clitoroglanuloplasty (4) and a NVP are required. Furthermore, this last one, when vaginal implantation was in the upper urethra, had a good indication for some type of abdominal-perineal approach. However, this tends to be changed after the emergence of the posterior sagittal sacroperineoplasty (PSSP), a technique updated in 1982 by Peña (8), to redress rectoanal abnormalities, who also used it for the correction of cloacal persistences (20) and for post-surgical fecal incontinence (15). On the other hand, a median vaginal atresia with anal imperforation (9) and a penile agenesis (24) were respectively corrected by the "Kraske" and "Cripps" approaches. All of these approaches gained such a momentum that they were indicated for children bearing perineal disorders requiring further surgeries (17), in the complex abnormalities of female genitalia $(11,12)$, for recto-vaginal (1), rectoperineal $(19)$ and urethral $(10,19)$ trauma, in the ressection of rectum tumors and repeated surgeries of the Hirschsprung disease (19) and currently reached a peak with the use of the PSTSARUVP, in cases of intersexuality with UGS and normal rectum $(19,21)$, thus bringing forth a complete modification of the surgical panorama regarding the management of the perineal region and to the external genitalia, moreover, often avoiding laparotomy.
Peña $(19,21,25)$ points out that to utilize the "Posterior sagittal transsphinctericanorectalplasty" (PSTSARP), a fecal deviation by means of a sigmoidostomy in separate openings is required, to avoid complications or severe consequences. Such requirement is confirmed by the author himself (19) in his bibliographic survey of 228 cases, submitted to PSTSARP with no colostomy. In this group there was a $13 \%$ contamination whereas those operated with protective colostomy did not exhibit such complications.

In the literature reviewed by Peña (19), only 20 cases submitted to PSTSARP with colostomy were recorded, and to those we add our results (cases 1,2 and 3 ) summing up 23 reported cases. It is perceivable that the association of PSTSARP with colostomy meets some reluctance. Nevertheless, we agree with Peña (19), that $13 \%$ of complications is a high rate and as an alternative to avoid colostomy we suggest a 10 days long parenteral nutrition, however associated to a careful cleaning of the whole bowel.

PSTSARP, known as the "Cripps" or "Kraske" (19) approach, had been essentially performed in adults until Dimler (9), Stealer (24) and Peña $(19,21)$ began to utilize it in children to achieve a better access to the vagina or to UGS, as well as to the inferior urinary tract.

The evolution of the posterior sagittal pathway has an interesting history: beginning in 1835, when "AMUSSAT" performed for the first time the posterior sagittal incision, followed by "VERNEUIL" employed the coccygectomy in 1873 for the first time, and "CRIPPS" 
who in 1876 employed the PSTSARP for the first time (19). This PSTSARP has been adapted by a series of authors like Kraske (19) in 1885, Bevan in 1917, Dimler in 1986 (9) and Peña 1992 (19). Now, when for the first time in Brazil, we are utilizing PSTSARP for intersexuated girls, Table 7.

The PSTSARP access pathway represents an extraordinary and marvellous approach, with integral preservation of the defecation and urinary controls, because the whole procedure is performed precisely on the midline, without nerve impairment (21).

Such pathway enhances further separation of the vagina from the urethra and bladder, affords a better mobilization from the vagina to the perineum, and moreover, avoids the utilization of perineal skin flaps. Therefore there is an almost total absence of stenosis of the vulvar introitus (21). On the other hand, Peña (21) does not recommend it for UGS with low vaginal implantation.

Regarding intersexuated patients, only three cases of FPH operated by PSTSARP are reported. One was an $\mathbf{A C H}(19,21)$, and the others were non adrenal FPH (21).
Our patient (case 1) was a $\mathbf{F P H}$, bearer of $\mathbf{A C H}$ with "salt loosing" and the others (cases 2 and 3) were MPH type I, incomplete syndrome; One was TFS and the other TRS.

The ages of the three patients with FPH quoted by Peña $(19,21)$ were 16,17 and 24 months. Conversely, our cases are adolescents with 13,14 and 15 years of age.

We believe that currently puberty is the ideal age to perform this type of surgery, the NVP, because of the socioeconomic shortcomings inherent to our environment, as well as because of the effect of the estrogenic action, benefical for the development of the vagina and cicatrization of the vulvar plasty (18). Although, at this age, as a resit of the growth of the pelvis, the distance from the beginning of the UGS (junction of the vagina with the urethra) to the perineum (common channel of the urogenital sinus) becomes longer, thus turning more difficult the mobility from the vagina to the perineum as compared to that of a child operated at two years of age. In the last one obviously, the common channel is shorter, therefore surgery is easier; However, when girls are submitted to an early surgery they are in danger of

Table 7

History of the posterior sagittal incision

INTERSEXUALITY UNIT - CHILDREN'S HOSPITAL "DARCY VARGAS"

TRANSSPHINCTERICANORECTALURETHROVAGINOPLASTY

HISTORY

\begin{tabular}{llll} 
AUTHORS & YEARS & SURGERIES & COUNTRIES \\
AMUSSAT & 1835 & "PSARPIARA" & FRANCE \\
MATAS & 1897 & "PSARPIARA" & UNITED STATES \\
PENA & 1982 & "PSARPIARAC" & MEXICO \\
CRIPPS & 1907 & "PSTSARPIRCA" & ENGLAND \\
KRASKE & 1916 & "PSTSARPIRCA" & GERMANY \\
BEVAN & 1917 & "PSTSARPIRCA" & UNITED STATES \\
DIMLER & 1986 & "PSTSARPIVAC" & UNITED STATES \\
PENA & 1992 & "PSTSARPIAGC" & UNITED STATES \\
BRAZ & 1993 & "PSTSARPIAGC" & BRAZIL \\
BRAZ & 1994 & "PSTSARUVSPIAGC" & BRAZIL \\
\hline
\end{tabular}

$(P S A R P)$

(ARA)

(ARAC)

(PSTSARP)

(RCA)

( $V A C)$

(AGC)

(PSTSARUVSP)
POSTERIOR SAGITTAL ANORECTALPLASTY

ANORECTAL ABNORMALITY

ANORECTAL ABNORMALITY IN CHILDHOOD

POSTERIOR SAGITTAL TRANSSPHINCTERICANORECTALPLASTY

RECTUM CANCER IN THE ADULT

VAGINAL ATRESIA IN CHILDHOOD

AMBIGUOUS GENITALIA IN CHILDHOOD

POSTERIOR SAGITTAL TRANSSPHINCTERICANORECTALURETHROVAGINOSIGMOIDPLASTY 
presenting a stenosis of the vulvar introitus due to lack of vaginal enlargement and will probably be submitted to another surgery in puberty $(2,18)$. Even though Peña (21) states that "widening is not required and that the vaginal opening has shown to be adequate 2 years after surgery". Nevertheless we can state that upon reaching puberty they shall not have sufficient width of the vulvar introitus to achieve adequate sexual intercourse and will require a vulvar plastic surgery.

\section{CONCLUSIONS}

This is an original presentation as it reports on the first time a PSTSARUVP was performed in the country, on intersexuated patients.

We present the first case to be published in global literature of a girl submitted to PSTSARUVP, bearer of FPH with $\mathbf{A C H}$ that was reassigned for the female gender as well as the fourth patient with $\mathbf{A C H}$ to be submitted to this approach (case 1).

In the reviewed literature no mention was found on MPH, type I incomplete form (TFS or TRS) operated by PSTSARUVP, therefore they will be the first PSTSARUVP for MPH to be published worldwide (cases 2 and 3 ).

Excluding repair of the rectoanal and cloacal malformations, there is no Brazilian or maybe Latin-
American recorded report on the utilization of PSTSARUVP with protective sigmoidostomy for the correction of AG (intersexuated patients) with UGS, high vaginal implantation (agenesis) and normal rectum, be it for FPH or any form of MPH.

Finally, these patients, unfortunately born with some abnormality of the genitalia can now a days to be available with a management that will hopefully warrant a better quality of life (with less morbidity, etc.) and is mainly related to sexual intercourse and to the possibility of procreation, thanks to the approach known as the "Cripps or Kraske" procedure (19), and reintroduced by Peña as the PSTSARUVP, improved by the utilization of electrocautery and electromiostimulation devices, thus shortening time of surgery and enhancing results, principally if performed by surgeons with a reasonable experience on the posterior sagittal pathway.

\section{AKNOWLEDGMENTS}

To Dr. Zan Mustachi pediatrician and geneticist of the CHDV, who during these 17 years has devoted himself to the care and aided in the guidance of the patients quoted in this and other published papers. To Drs. José Carnevale and Roberto Dias for the endoscopic assays, attendance and dedication to the patients.

\section{RESUMO}

Introdução: Os autores, baseados numa prévia experiência no tratamento de dez crianças com anomalias de cloaca, dentre estas, duas com pseudo-hermafroditismo feminino com cloaca, apresentam agora uma experiência com a "transesfincteroanoretouretrovaginoplastia sagital posterior" com colostomia protetora, técnica de neovaginoplastia descrita por "Cripps/Peña". que foi aplicada na correçāo das genitálias de três adolescentes intersexuadas que apresentavam "sinus" uro-genital, implantaçăo vaginal alta e reto normal. Material e Métodos: Uma paciente era portadora de pseudo-hermafroditismo feminino adrenal e duas eram pseudo-hermafroditas masculino, tipo I sindrome incompleta. Apresentam um breve relato dos très casos, descrevem a técnica cirùrgica utilizada, discorrem sobre a anatomia do "sinus" uro-genital e discutem as indicaçōes cirúrgicas, os diagnósticos e os resultados, comparando-os aos da literatura mundial pesquisada. 


\section{REFERENCES}

1. APPLEBAUN, H. \& ATKINSON, J.B. - The posterior sagittal approach for reconstruction of severe rectovaginal injuries. J Ped Surg, 26:856-857, 1991.

2. BRAZ, A. - Unidade de Intersexo: casuística e experiência de 12 anos. Ped Mod, 28:349-375, 1992.

3. BRAZ, A.; CARNEVALE, J. \& MUSTACHI, Z. - Intersexo: genitália ambígua. In: Segre, C.A.M.; Armelini P.A. - Recémnascido (RN). 248-251. Såo Paulo, Sarvier, 1985.

4. BRAZ, A.; DONDA, A.C. \& GIACCIO, C.D. Clitoroglandoplastia redutora subtunical: modificações de técnicas existentes. Ped Mod, 24:281-297, 1989.

5. BRAZ, A.; DONDA, A.C.; SOBREIRO, A.R.; MONTEIRO, R.C.; MARQUES, S.G. \& MUSTACHI, Z. Intersexualidade: redesignação sexual na adolescência com fertilidade e concepção. Ped Mod, 27:505-520, 1991.

6. BRAZ, A.; SAMPAIO, D.S.; REIS, M.S. \& MUSTACHI, Z. - Organização, funcionamento de uma unidade de intersexo. Ped Quir Panam, 12:26-35, 1984.

7. BROCK, W.A. \& PEÑA, A. - Cloacal Abnormalities and Imperforate Anus. In: Kelalis, P.P.; King L.R.; Belman, A.B. - Clinical Pediatric Urology. 920-941. Philadelphia, WD Saunders Co, 1992.

8. deVRIES, P.A. \& PEÑA, A. - Posterior sagittal anorectoplasty. J Ped Surg, 17:638-643, 1982.

9. DIMLER, M. \& MOODY, J. - The posterior sagittal approach to repair of vaginal atresia and imperforate anus. Amer Surg, 52:72-75, 1986.

10. FLAH, L.M.; ALPUCHE, J.O.C. \& CASTRO, R.S. - Repair of posttraumatic stenosis of the urethra through a posterior sagittal approach. J Ped Surg, 27:1465-1470, 1992.

11. KARLIN, G.; BROCK, W.; RICH, M. \& PEÑA, A. Persistent cloaca and phallic urethra. J Urol, 142:1056-1059, 1989.

12. LEDITSCHKE, J.F. \& PEÑA, A. - An unusual cloacal anomaly: late recognition and operative correction. Ped Surg Int, 6:52-55, 1991.
13. PEÑA, A. - Atlas of Surgical Management of Anorectal Malformations. 49-77. New York, Springer-Verlag, 1990.

14. PEÑA, A. - Persistent Cloaca. In: Frank, J.D.; Johnston, J.H. - Operative Paediatric Urology. 134-150. London, Churchill Livingstone, 1990.

15. PEÑA,A.- Posterior sagittal anorectoplasty as a secondary operation for the treatment of fecal incontinence. J Ped Surg, 18:762-773, 1983.

16. PEÑA, A. - Posterior sagittal anorectoplasty: results in the management of 332 cases of anorectal malformations. Ped Surg Int, 3:94-104, 1988.

17. PEÑA, A. - Surgical treatment of anorectal malformations, a unified concept. J Ped Surg, 3:82-93, 1988.

18. PEÑA, A. - The surgical management of persistent cloaca: results in 54 patients treated with a posterior sagittal approach. J Ped Surg, 24:590-598, 1989.

19. PEÑA, A.; BONILLA, E.; MENDEZ, M \& SANCHEZ, L. The posterior sagittal approach: further pediatric applications. Ped Surg Int, 7:274-278, 1992.

20. PEÑA, A. \& deVRIES, P.A. - Posterior sagittal anorectoplasty: important technical considerations and new applications. J Ped Surg, 17:796-811, 1982.

21. PEÑA, A.; FILMER, B.; BONILLA, E.; MENDEZ, M. \& STOLAR,C. - Transanorectal approach for the treatment of urogenital sinus: preliminary report. J Ped Surg, 27:681$685,1992$.

22. ROSENBERG, C.; MUSTACHI, Z.; BRAZ, A.; ARNHOLD, I.J.P.; CHU, T.H.; CARNEVALE, J. \& FROTA-PESSOA, O.; - Testicular regression in a patient with virilized female phenotype. Amer J Med Genet, 19:183-188, 1984.

23. SAMPAIO, D.S.; PAIVA, M.R.; MUSTACHI, Z.; BRAZ, A. \& MOREIRA, C.A. - Psicologia da intersexualidade humana. Rev Ciên \& Cult, 33:911-919, 1981.

24. STOLAR, C.J.H.; WIENER, E.S.; HENSLE, T.W.; SILEN, M.L.; SUKAROCHANA,K.; SIEBER, W.K.; GOLDSTEIN, H.R. \& PETTIT,J. - Reconstruction of penile agenesis by a posterior sagittal approach. J Ped Surg, 22:1076-1080, 1987.

25. WILKINS, S. \& PEÑA, A. - The role of colostomy in the management of anorectal malformations. Ped Surg Int, 3:105-109, 1988. 